\title{
MAMOGRAFIJOS METU KRŪTŲ SKAUSMĄ SUKELIANČIŲ VEIKSNIŲ ANALIZE்
}

\author{
Arvydas Martinkėnas ${ }^{1}$, Birutė Strukčinskienė ${ }^{1}$, Diana Šopagienė², \\ Dovilè Mažonaite் ${ }^{1}$, Sigitas Griškonis ${ }^{1,3}$ \\ ${ }^{1}$ Klaipédos universiteto Sveikatos mokslu fakultetas, ${ }^{2}$ Lietuvos sveikatos mokslu universiteto \\ Medicinos akademijos Medicinos fakulteto Radiologijos klinika, ${ }^{3}$ Klaipédos universitetine ligoninè
}

Raktažodžiai: mamografija, skausmas mamografijos metu, krūties vėžys.

\section{Santrauka}

Mamografija - tai specialus radiologinis krūtų audinio diagnostinis tyrimas, padedantis diagnozuoti piktybinius ir gerybinius pakitimus krūtyse. Šis tyrimas naudojamas ne tik krūtyse apčiuopiamų darinių ar kitų pakitimų diagnostikai. Krūties vèžio atrankinių patikrų metu jis taikomas ir nesant simptomų. Mamografijos tyrimas turi ne tik privalumų, bet ir trūkumų. Vienas iš trūkumų - skausmas, kurị mamografijos metu sukelia krūties suspaudimas, būtinas sumažinti apšvitos dozę, užkirsti kelią judesio artefaktams ir gauti suplotą krūties audinio vaizdą. Tyrimo tikslas - atskleisti veiksnius, sukeliančius krūtų skausmą diagnostinès mamografijos tyrimo metu.

Atlikta anoniminé apklausa Klaipédos ligoninèje. Apklausoje dalyvavo 202 moterys, įtrauktos ị prevencinę mamografijos programą. Tyrimo metu buvo siekiama išsiaiškinti veiksnius, sukeliančius skausmą mamografijos tyrimo metu. Tyrimo duomenų apdorojimui ir rezultatų skaičiavimui naudota statistinès analizès ir duomenų apdorojimo programinè įranga Microsoft Office Excel 2016 ir SPSS (27 versijos) programa. Kintamuju priklausomumui vertinti naudotas Chi kvadrato $\left(\chi^{2}\right)$ testas. Lyginant tiriamujų grupių statistinị duomenų skirtumą, patikimumas tikrintas pagal z kriterijų. Rezultatai laikyti statistiškai reikšmingi, kai $\mathrm{p}<0,05$. Tyrimo metu nustatyta, kad skausmo nejaute 57 proc. tiriamujų, o kitos (43 proc.) - jautè. Silpną skausmą jautė 23 proc. moterų, vidutini -11 proc., stipru -6 proc., o labai stipru skausmą jaute 3 proc. moterų. Skausmas priklausè nuo krūtų dydžio, neprasidejusios (prasidejjusios) menopauzès ir nuo neskausmingų (skausmingų) krūtų $(\mathrm{p}<0,001)$. Iš visu apklausos dalyviu 3 proc. respondenčiu atsisakytu kito mamografijos tyrimo. Dauguma jų atsisakytų pro- cedūros dèl mamografijos metu patirto stipraus bei labai stipraus skausmo.

Išvados. Veiksniai, sukèlę krūtų skausmą mamografinio tyrimo metu, buvo mažas krūtų dydis, neprasidejusi menopauzè, skausmingos krūtys. Mamografijos tyrimo metu skausmą jautė beveik pusè tirtų moterų. Dalis moterų, jautusių labai stiprų arba stiprų skausmą, tokio tyrimo atsisakytų.

\section{İvadas}

Vèžinai susirgimai yra vienas iš pagrindinių mirčių sukèlëjų ne tik Lietuvoje, bet ir visame pasaulyje. 2020 metų duomenimis, pasaulyje užregistruota apie $19 \mathrm{mln}$. naujų vėžinių susirgimų, iš kurių 11,7 proc. sudaro krūties vėžys [1]. Krūties vèžys yra dažniausia moterų mirties dẻl piktybinių navikų priežastis išsivysčiusiose ir besivystančiose šalyse [2]. Krūties vèžio rodikliai kasmet dideja daugelyje šalių. PSO duomenimis, Lietuvoje 2020 metais nustatyta apie 1769 naujus krūties vèžio atvejus.

Mamografija - tai svarbiausiais krūtų ligų diagnostinis tyrimas, kuriuo atliekama pirminẻ krūties vėžio diagnostika. Šio radiologinio tyrimo tikslai yra ankstyvojo krūties vėžio diagnostika nesant ligos simptomų ir diagnozès nustatymas pacientèms, jau turinčioms simptomų [3]. Remiantis M. Løberg su bendraautoriais [4], ši onkologinè liga turi būti nustatoma kuo ankstesnès stadijos ir kuo skubiau gydoma, siekiant sumažinti mirčių skaičių. Diagnostikos būdas, padedantis nustatyti ankstyvos stadijos krūties vėži, yra atrankinè mamografinè patikra, kurioje dalyvauja tam tikrų amžiaus grupių moterys, neturinčios krūties vėžio simptomų ir požymių. Periodiškai vykdoma atrankinès mamografijos patikra padeda anksti nustatyti krūties vėži, kol jis dar nesukèlè simptomų. Atrankinių mamografinių patikrų naudą įrodė patikros programų rezultatai. Nustatyta, kad mirtingumas, vykdant atrankinę mamografinę patikrą, gali sumažèti nuo 20 iki 35 procentų [5-7]. 
Mamografijos tyrimas yra saugi procedūra, turinti ne tik privalumų, bet ir trūkumų $[4,7]$. Vienas iš dažniausiai literatūroje minimų trūkumų - skausmas. Literatūroje P. Whelehan su bendraautoriais nurodo, kad skausmas pasireiškia 25-46 proc. atvejų, todèl moterys daugiau neatlieka mamografijos tyrimų [8]. Mamografijoje skausmą sukelia krūties suspaudimas, kuris yra būtinas sumažinti apšvitos dozę, užkirsti kelią judesio artefaktams ir gauti suplotą krūties audinio vaizdą [9]. Iki šiol Lietuvoje nebuvo atlikta išsamių tyrimų, kuriuose būtų pateikiami mo-

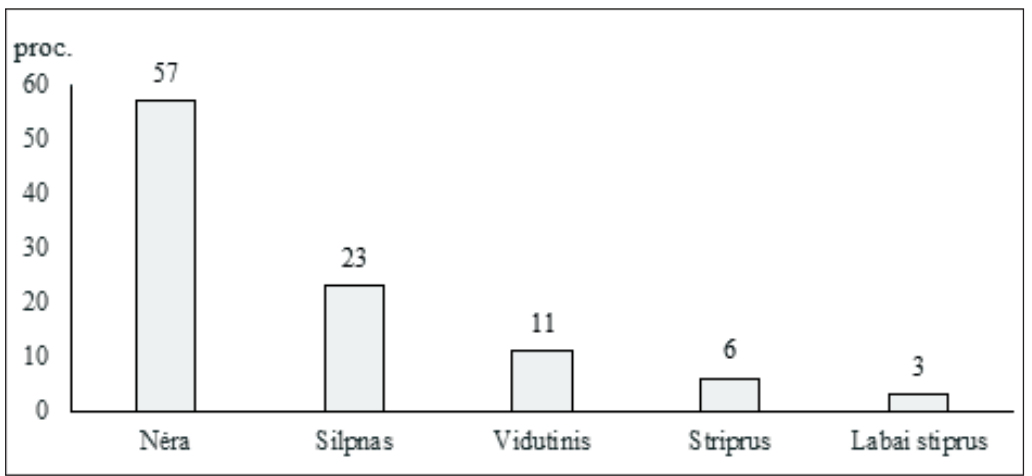

1 pav. Skausmas, jaučiamas mamografijos metu terų, jautusių skausmą mamografijos metu, tyrimo duomenys. Šiuolaikineje mamografijoje taikomi įvairūs būdai, kuriais siekiama sumažinti patiriamą skausmą ir diskomfortą tyrimo metu [9].

Tyrimo tikslas - atskleisti veiksnius, sukeliančius krūtų skausmą diagnostinès mamografijos tyrimo metu.

\section{Tyrimo medžiaga ir metodai}

Kiekybiniam tyrimui atlikti buvo atlikta anoniminè anketinè apklausa. Apklausa vykdyta $2021 \mathrm{~m}$. kovo - balandžio mèn. vienoje Klaipėdos miesto ligoninèje, gavus Klaipėdos ligoninès vadovo leidimą. Klausimynas sudarytas vadovaujantis moksline literatūra apie mamografiją $[3,8,10,11]$. Klausimyną sudare 17 uždaro tipo ir 1 atviro tipo klausimas. Anketinès apklausos metodu buvo sužinota apie veiksnius, nuo kuriu gali priklausyti skausmas mamografijos tyrimo metu ir išsiaiškintas sukelto skausmo poveikis pacientès požiūriui ị mamografiją. Duomenys buvo renkami apie amžių, krūtų dydị, prasidejjusią (neprasidèjusią) menopauzę, krūtų skausmą, kontraceptikų vartojimą.

Tyrime dalyvavo moterys, ịtrauktos ị prevencinę mamografijos programą, kuri vykdoma nuo 50 iki 69 metų amžiaus moterims. Pacientès buvo atrinktos sisteminès imties būdu. Išdalinta 250 anketų. I tyrimą ịtrauktos 202 dalyvès, kurios tinkamai užpildė anketas - anketų grịžtamumas sudarẻ 81 procentą.

Statistinė duomenų analizė. Statistinei duomenų analizei naudota Microsoft Office Excel 2016 ir IMB SPSS 27 versijos paketai. Kintamujų priklausomumui vertinti naudotas Chi kvadrato $\left(\chi^{2}\right)$ ir Fišerio tikslusis kriterijus. Lyginant tiriamujų grupių statistinį duomenų skirtumą, patikimumas buvo tikrintas pagal z kriterijų. Rezultatai laikomi statistiškai reikšmingi, kai $\mathrm{p}<0,05$.

\section{Tyrimo rezultatai ir jụ aptarimas}

Literatūroje akcentuojama, kad viena dažniausių problemų, su kuria susiduria pacientės mamografijos tyrimo

metu, yra skausmas. Mūsų tyrimas atskleidè, kad iš 202 respondenčių skausmą jaute 43 proc. tiriamujų, o kitos (57 proc.) skausmo nepajuto (1 pav.).

Panašius rezultatus pateikia savo tyrime ir F. Sardanelli su bendraautoriais [3] - skausmo nejautè apie 40-50 proc. moterų, tačiau N. Akansel ir kt. atskleide, kad skausmą jautė 78,8 proc. tirtų respondenčių [10].

Tyrimo rezultatai parodé, kad 78 proc. moterų žinojo, kad mamografinis tyrimas gali būti skausmingas, o nežinojo 22 proc. respondenčių. Daugiau nei pusė respondenčių apie

1 lentelè. Mamografijos metu skausmingumą galintys sukelti veiksniai.

\begin{tabular}{|c|c|c|}
\hline Veiksniai & $\begin{array}{c}\text { Tiriamųjų } \\
\text { skaičius (n) }\end{array}$ & $\begin{array}{l}\text { Tiriamujjų dalis } \\
\text { (proc.) }\end{array}$ \\
\hline \multicolumn{3}{|l|}{ Moterų amžius } \\
\hline $50-54$ & 69 & 34,2 \\
\hline $55-59$ & 49 & 24,3 \\
\hline $60-64$ & 50 & 24,7 \\
\hline $65-69$ & 34 & 16,8 \\
\hline \multicolumn{3}{|l|}{ Krūtų dydis } \\
\hline Mažos (A dydis) & 66 & 32,7 \\
\hline Vidutinès ( $\mathrm{B}-\mathrm{C}$ dydis) & 66 & 32,7 \\
\hline Didelès ( $\mathrm{D}$ ir didesnès) & 70 & 34,6 \\
\hline \multicolumn{3}{|l|}{ Prasidèjusi menopauzè } \\
\hline Taip & 185 & 91,6 \\
\hline $\mathrm{Ne}$ & 17 & 8,4 \\
\hline \multicolumn{3}{|l|}{ Krūtys skausmingos } \\
\hline Taip & 42 & 20,8 \\
\hline $\mathrm{Ne}$ & 160 & 79,2 \\
\hline \multicolumn{3}{|l|}{ Kontraceptikų vartojimas } \\
\hline Taip & 28 & 13,9 \\
\hline $\mathrm{Ne}$ & 174 & 86,1 \\
\hline
\end{tabular}


skausmą sužinojo iš radiologijos technologo, kitos - iš gydytojo (20 proc.), iš žiniasklaidos (11 proc.), iš interneto, iš šeimos, draugų ar artimujų. Tik 5 proc. respondenčių apie skausmą mamografijoje sužinojo iš kitur. Apklausoje 60 proc. respondenčių mano, kad skausmas priklauso nuo radiologijos technologo veiksmų mamografijos metu. Apklausos rezultatai parodé, kad prieš tyrimą 78 proc. radiologijos technologų perspejo apie skausmą, atliekant mamografiją.

Apklausoje buvo renkami duomenys apie veiksnius, kurie gali turèti įtakos jaučiamam skausmui tyrimo metu, t.y. krūtų dydis, prasidèjusi menopauzè, kontraceptikų vartojimas ir kt. (1 lentelè). Pagal amžių dalyvès buvo suskirstytos ị 4 grupes. Daugiausia apklausoje dalyvavo $50-54$ metų moterų. $55-59$ ir 60

2 lentelè. Skausmo priklausomybė nuo amžiaus.

\begin{tabular}{|c|c|c|c|c|c|c|c|}
\hline \multirow{3}{*}{$\begin{array}{l}\text { Amžiaus } \\
\text { grupės }\end{array}$} & \multicolumn{5}{|c|}{ Skausmas } & \multirow{3}{*}{ p } & \multirow{3}{*}{$\chi^{2}$} \\
\hline & nèra & silpnas & vidutinis & stiprus & labai stiprus & & \\
\hline & \multicolumn{5}{|c|}{$\mathrm{n}$ (proc.) } & & \\
\hline $50-54$ & $36(52,2)$ & $11(15,9)$ & $13(18,8)$ & $6(8,7)$ & $3(4,3)$ & \multirow{4}{*}{0,296} & \multirow{4}{*}{14,075} \\
\hline $55-59$ & $30(61,2)$ & $14(28,6)$ & $1(2,0)$ & $3(6,1)$ & $1(2,0)$ & & \\
\hline $60-64$ & $30(60,0)$ & $12(24,0)$ & $5(10,0)$ & $1(2,0)$ & $2(4,0)$ & & \\
\hline $65-69$ & $19(55,9)$ & $9(26,5)$ & $4(11,8)$ & $2(5,9)$ & $0(0,0)$ & & \\
\hline
\end{tabular}

3 lentelè. Skausmo priklausomybė nuo krūtų dydžio

\begin{tabular}{|c|c|c|c|c|c|c|c|}
\hline \multirow{3}{*}{$\begin{array}{l}\text { Krūtų } \\
\text { dydis }\end{array}$} & \multicolumn{5}{|c|}{ Skausmas } & \multirow{3}{*}{$\mathbf{p}$} & \multirow{3}{*}{$\chi^{2}$} \\
\hline & nèra & silpnas & vidutinis & stiprus & $\begin{array}{c}\text { labai sti- } \\
\text { prus }\end{array}$ & & \\
\hline & \multicolumn{5}{|c|}{$\mathrm{n}$ (proc.) } & & \\
\hline Mažos & $22(33,3)$ & $16(24,2)$ & $\begin{array}{c}13 \\
(19,7)\end{array}$ & $10(15,2)$ & $5(7,6)$ & \multirow{3}{*}{$<0,001$} & \multirow{3}{*}{46,288} \\
\hline Vidutinès & $37(56,1)$ & $18(27,3)$ & $9(13,6)$ & $1(1,5)$ & $1(1,5)$ & & \\
\hline Didelès & $56(80,0)$ & $12(17,1)$ & $1(1,4)$ & $1(1,4)$ & $0(0,0)$ & & \\
\hline
\end{tabular}

4 lentelè. Skausmo priklausomybè nuo amžiaus ir krūtų dydžio.

\begin{tabular}{|c|c|c|c|c|c|c|}
\hline \multirow{3}{*}{$\begin{array}{l}\text { Amžiaus } \\
\text { grupès }\end{array}$} & \multirow{3}{*}{ Krūtų dydis } & \multicolumn{5}{|c|}{ Skausmas } \\
\hline & & nèra & silpnas & vidutinis & stiprus & labai stiprus \\
\hline & & \multicolumn{5}{|c|}{ proc. } \\
\hline \multirow{3}{*}{$50-54$} & Mažos & 6,8 & 8,6 & 39,1 & 50,0 & 50,0 \\
\hline & Vidutinès & 14,0 & 8,6 & 17,2 & - & - \\
\hline & Didelès & 9,6 & 6,2 & - & - & - \\
\hline \multirow{3}{*}{$55-59$} & Mažos & 4,9 & 15,4 & - & 16,4 & 16,4 \\
\hline & Vidutinès & 10,7 & 6,2 & 4,8 & 8,3 & - \\
\hline & Didelès & 10,7 & 8,4 & - & - & - \\
\hline \multirow{3}{*}{$60-64$} & Mažos & 3,0 & 2,8 & 8,4 & - & 16,8 \\
\hline & \begin{tabular}{|l|} 
Vidutinès \\
\end{tabular} & 3,9 & 19,7 & 8,4 & - & 16,8 \\
\hline & Didelès & 19,1 & 4,7 & 4,6 & 8,3 & - \\
\hline \multirow{3}{*}{$65-69$} & Mažos & 3,8 & 8,2 & 4,6 & 17,0 & - \\
\hline & Vidutinès & 3,8 & 4,7 & 12,9 & - & - \\
\hline & Didelès & 9,7 & 6,4 & - & - & - \\
\hline
\end{tabular}

- 64 metų tyrimo dalyvių skaičius buvo panašus, o mažiausiai dalyvavo vyriausių $65-69$ metų moterų. Krūtų dydis suskirstytas ị tris grupes: mažos, vidutinès ir didelès. 33 proc. sudare mažos ir vidutinès krūtys, didelès - 34 proc.; tyrime nebuvo krūtų dydžio dominavimo - dydžiai pasiskirstè panašiai. 21 proc. respondenčių pažymèjo turinčios skausmingas krūtis, o kontraceptikus vartojo 14 proc. moterų.

Literatūroje nurodyta, kad amžius gali būti vienas iš veiksnių, turinčių itakos pacienčių skausmui mamografijos metu. Palyginę tyrimo rezultatus (2 lentelè), nustatėme, kad didesnį skausmą patiria 50-54 metų moterys. Jauniausio amžiaus grupés moterys apie 9 proc. jaučia dažniau skausmą, palyginus su 55 - 59 metų moterimis, 8 proc. dažniau nei $60-64$ metų moterys ir apie 4 proc. dažniau, nei vyriausios amžiaus grupès moterys. 50-54 metų tiriamosios nurode jautusios vidutini, stipresnị ir labai stiprų skausmą dažniau, o silpnesnị - rečiau nei vyresnio amžiaus grupių moterys. Statistinis ryšys tarp amžiaus ir skausmo nebuvo statistiškai reikšmingas $(\mathrm{p}>0,05)$.

Krūtų dydis yra vienas iš reikšmingų veiksnių, galintis sukelti skausmą atliekant mamografini tyrimą. Mūsų tyrimo metu gauti rezultatai (3 lentelè) atskleidè, kad moterys, turinčios mažas krūtis (A dydžio), labiau jaučia skausmą, o 80 proc. dideles krūtis turinčių moteru visai nejaučia skausmo. Vidutines krūtis turinčios moterys dažniausiai jaučia silpną skausmą $(\mathrm{p}<0,05)$.

Vertinant skausmo mamografinio tyrimo metu priklausomybę nuo amžiaus ir krūtų dydžio (4 lentelè), nustatėme, kad mažas krūtis turinčios jauniausio amžiaus grupès (50-54 m.) moterys dažniausiai jautė stiprų ir labai stiprų skausmą (net 50 proc.), vidutini skausmą jaute 39,1 proc. šios amžiaus grupès tiriamujjų. Kitų amžiaus grupių mažas krūtis turinčios moterys stiprų ir labai stiprų skausmą jaute rečiau, nei 
grupëje nuo 50 iki 54 metų. Vidutines krūtis turinčios moterys dažniausiai jautè silpną, vidutinị skausmą arba jo net nejautè, tačiau 55-59 metų amžiaus grupés moterys nejautė vidutinio skausmo, bet jautè stiprų skausmą ( 8,3 proc.) radiologinio tyrimo metu. Dideles krūtis turinčios moterys visose amžiaus grupése jaute silpną skausmą arba nejautè, tačiau dideles krūtis turinčios 60-64 metų moterys jautè vidutini ( 4,6 proc.) ir stiprų ( 8,3 proc.) krūtų skausmą mamografinio tyrimo metu.

Iš 202 apklaustujų menopauzė buvo prasidejusi 185 moterims. Mamografinio tyrimo metu 76 proc. moteru, kurioms nebuvo prasidèjusi menopauzè, dažniausiai jautè vidutinị skausmą (5 lentelè), o 40 proc. moterų, kurioms menopauzè buvo prasidejusi, skausmą jautè, Neskausmingos krūtys buvo 160, skausmingos - 42 tiriamujjų. Skausmingas krūtis turinčios moterys skausmą mamografinio tyrimo metu jautė dažniau (57 proc.), nei turinčios neskausmingas. Skausmingas krūtis turinčios moterys dažniausiai jautė silpną ir vidutinį skausmą.

Nustatėme, kad skausmas mamografinio tyrimo metu nepriklauso nuo kontraceptiku vartojimo $(p>0,07)$, tačiau priklauso nuo skausmingų krūtų ir neprasidejusios menopauzès $(p<0,0)$. Kai kurie autoriai nurodo [10], kad nèra skausmo priklausomybès nuo krūtų dydžio, prasidèjusios (neprasidèjusios) menopauzès. Mūsų tyrime gauti rezultatai sutampa su literatūros duomenimis, kad skausmas priklauso nuo skausmingų krūtų, o nepriklauso nuo amžiaus. Nors N. Akansel su bendraautoriais teigia, kad skausmas nepriklauso nuo krūtų dydžio [10], tačiau K. Feder su bendraautoriais savo tyrime nurodo, kad krūtų dydis turi įtakos skausmui ir mažas krūtis turinčios moterys mamografijos metu dažniau jaučia stipresnị skausmą [11].

Iš visų apklausos dalyvių dar kartą mamografinio tyrimo nenoretų atlikti 3 proc. moterų. Dar kartą mamografijos neatliktų pusė moterų, kurios jautẻ labai stiprų skausmą ir ketvirtadalis tų, kurios jautè stiprų skausmą (6 lentelè). Iš 115 moterų, kurios nejautė skausmo, viena daugiau neatliktų šio radiologinio tyrimo. Apibendrinant apklausos duomenis, galima teigti, kad iš nenorinčių dar kartą atlikti mamografinị tyrimą, 86 proc. moterų šio tyrimo daugiau neatliktų dèl stipraus ir labai stipraus skausmo procedūros metu.

P. Whelehan su bendraautoriais teigia, kad skausmas sudaro 25-46 proc. atvejų, todèl moterys nebeatlieka mamografijos tyrimų ateityje [8].

Mamografijos tyrimas ne pirmą kartą buvo atliktas 82,7 proc. respondenčių: vieną (18 proc.), du (15 proc.) ir tris (20 proc.) kartus. Daugiausia (47 proc. visų respondenčių) buvo moterų, kurioms mamografija atlikta 4 kartus arba daugiau. Dideli skaičių moterų, atlikusių mamografijos tyrimą 4 ir daugiau kartų lèmè tai, kad vykdoma prevencinė programa, atliekama kas dvejus metus. Moteris, nuosekliai vykdanti prevencinę programą, iki 69 metų turi atlikti 10 mamografijos tyrimų.

Mūsų tyrimo rezultatai iš dalies gauti panašūs, kaip pateikiami literatūroje, nors ne visur sutapo. Galima teigti, kad skausmui turi įtakos krūtų dydis, skausmingos krūtys, prasidejusi (neprasidèjusi) menopauzè, o skausmas, juntamas mamografijos metu, yra priežastis, dèl kurios moterys atsisako šią procedūrą atlikti dar kartą.

Siekiant sumažinti skausmą mamografijos tyrimo metu, rekomenduojama reprodukcinio amžiaus moteris registruoti tyrimui, atsižvelgiant ị menstruacijų ciklo dienas. Geriausias laikas atlikti mamografiją yra nuo 7 iki 12 dienos nuo paskutinių moters mènesinių pradžios, nes tokiu metu krūtys nèra tokios jautrios ir skausmingos, todèl tyrimas sukels mažesnị diskomfortą. Nerekomenduojama tyrimą atlikti likus 2-3 dienoms iki mènesinių ar jų metu. Radiologijos technologui rekomenduojama perspèti apie mamografijos skausmą prieš kiekvieną procedūrą ir ypač dèmesingai elgtis su reprodukcinio amžiaus pacientemis, kurių krūtys yra mažos ir skausmingos. Radiologijos technologas po krūtų suspaudimo turi kuo skubiau atlikti mamogramą, kad skausmas būtų jaučiamas trumpesnį laiką.

Siekiant sumažinti skausmą tyrimo metu, turi būti atnaujinami ma-

5 lentelè. Skausmo priklausomybė nuo menopauzès ir krūtų skausmingumo.

\begin{tabular}{|l|l|l|l|l|l|l|l|}
\hline \multirow{2}{*}{ Veiksniai } & \multicolumn{5}{|c|}{ Skausmas } \\
\cline { 2 - 7 } & \multicolumn{2}{|c|}{ nėra } & silpnas & vidutinis & stiprus & $\begin{array}{l}\text { labai sti- } \\
\text { prus }\end{array}$ \\
\cline { 2 - 7 } & n (proc.) \\
\hline $\begin{array}{l}\text { Prasidejjusi meno- } \\
\text { pauzė }\end{array}$ & $111(96,5)$ & $45(97,8)$ & $16(69,6)$ & $8(66,7)$ & $5(83,3)$ \\
\cline { 2 - 7 } & Taip & $4(3,5)$ & $1(2,2)$ & $7(30,4)$ & $4(33,3)$ & $1(16,7)$ \\
\hline $\begin{array}{l}\text { Krūtys skausmin- } \\
\text { gos }\end{array}$ & Taip & $5(4,3)$ & $16(34,8)$ & $10(43,6)$ & $6(50,0)$ & $5(83,3)$ \\
\cline { 2 - 7 } & $\mathrm{Ne}$ & $110(95,7)$ & $30(65,2)$ & $13(56,5)$ & $6(50,0)$ & $1(16,7)$ \\
\hline
\end{tabular}

6 lentelè. Mamografijos atlikimo dar kartą dažnis.

\begin{tabular}{|l|l|l|l|l|l|l|}
\hline \multirow{2}{*}{$\begin{array}{l}\text { Mamografijos atli- } \\
\text { kimas dar kartą }\end{array}$} & nėra & skausmas & \multicolumn{4}{l|}{} \\
\cline { 2 - 6 } & $\mathrm{n}$ (proc.) & vidutinis & stiprus & labai stiprus \\
\hline Taip & $114(99,1)$ & $46(100,0)$ & $23(100,0)$ & $9(75,0)$ & $3(50,0)$ \\
\hline $\mathrm{Ne}$ & $1(0,9)$ & $0(0,0)$ & $0(0,0)$ & $3(25,0)$ & $3(50,0)$ \\
\hline
\end{tabular}


mografijos aparatai, kuriuose įdiegiamos šiuolaikinès technologijos, krūtų suspaudimo metu padedančios sumažinti skausmą mamografijos metu. Pavyzdžiui, krūtų kompresijai naudojant ne jeggą, o taikant slègi, naudojant „MammoPad“ pagalvėlę, arba atlikti krūties suspaudimą, kontroliuojant pacientei.

\section{Išvados}

1. Mamografija - pagrindinis krūties vėžio radiologinis tyrimas. Šis tyrimas yra specifiškas, turintis privalumų ir trūkumų. Pagrindiniai privalumai atliekant mamografiją ankstyvesnès vèžio stadijos aptikimas ir mirtingumo nuo krūties vėžio sumažèjimas. Trūkumai - klaidingi diagnostikos rezultatai, patirtas skausmas, apšvita. Nors mamografija turi trūkumų, tačiau šio tyrimo privalumai duoda daugiau naudos nei žalos, todèl diagnostiniais tikslais ji atliekama ne tik moterims, jau turinčioms simptomų, bet ir atrankinių patikrų metu, nesant simptomų.

2. Tyrimas atskleide, kad mamografinio tyrimo metu krūtų skausmą sukeliantys veiksniai yra mažos krūtys, neprasidejusi menopauzè, skausmingos krūtys. Skausmas mamografijos metu nepriklauso nuo amžiaus. Tyrime dalyvavusios jauniausio amžiaus grupès moterys dažniau jautè vidutinị, stiprų ir labai stiprų skausmą, palyginus su vyresnio amžiaus grupių moterimis.

3. Skausmą mamografinio tyrimo metu jautė apie pusė tyrime dalyvavusių moterų. Tyrimas parodè, kad dalis moterų, jautusių labai stiprų arba stiprų skausmą, atsisakytų kito mamografijos tyrimo.

\section{Literatūra}

1. WHO 2020. https://www.who.int/data/mortality/country-profile.

2. Aleknavičius E., Atkočius V., Bloznelytè - Plèšnienè L., Briedienė R., Bružas S., Bulotienè G. ir kt. Krūties vėžys: moksliniai ir klinikiniai aspektai. Mokslinė mokomoji monografija. Nacionalinis vėžio institutas: Vilnius, 2016.

3. Sardanelli F, Fallenberg EM, Clauser P, Trimboli RM, CampsHerrero J, Helbich TH et al. Mammography: An Update of the EUSOBI Recommendations on Information for Women. Insights into Imaging 2017;8:11-18.

https://doi.org/10.1007/s13244-016-0531-4

4. Løberg M, Lousdal ML, Bretthauer M, Kalager M. Benefits and harms of mammography screening. Breast Cancer Research 2015;17(1):63.

https://doi.org/10.1186/s13058-015-0525-z

5. Steponavičienė L., Briedienė R., Šenbergè S., Gudavičienė D., Smailytė G. Atrankinès mamografinès patikros vykdymo patirtis Nacionaliniame véžio institute. Sveikatos mokslai, 2017;27(6):161-168.

https://doi.org/10.5200/sm-hs.2017.113
6. Steponaviciene L, Vincerzevskiene I, Briediene R, Urbonas V, Vanseviciute-Petkeviciene R, Smailyte G. Breast Cancer Screening Program in Lithuania: Interval Cancers and Program Sensitivity After 7 Years of Mammography Screening. Cancer Control 2019;26(1): 1073274819874122.

https://doi.org/10.1177/1073274819874122

7. Otto PM, Christa BB. Controversies Surrounding Screening Mammography. Missouri Medicine 2014;111(5):439-443.

8. Whelehan P, Evans A, Wells M, Macgillivray S. The effect of mammography pain on repeat participation in breast cancer screening: a systematic review. Breast 2013;22(4):389-394. https://doi.org/10.1016/j.breast.2013.03.003

9. Broeders MJM, Voorde MT, Veldkamp WJH, van Engen RE, van Landsveld - Verhoeven C, Jong - Gunneman MNL et al. Comparison of a flexible versus a rigid breast compression paddle: pain experience, projected breast area, radiation dose and technical image quality. European Radiology 2015;25(3):821-829. https://doi.org/10.1007/s00330-014-3422-4

10. Akansel N, Gülşen M, Gültaş M. Influence of Discomfort Tolerance of Women who Undergo Mammography on the Perceived Pain Intensity Due to the Procedure. Eur J Breast Health 2020;17(1):68-75.

https://doi.org/10.4274/ejbh.2020.6068

11. Feder K, Grunert JH. Is Individualizing Breast Compression during Mammography useful? - Investigations of pain indications during mammography relating to compression force and surface area of the compressed breast. Rofo 2017;189(1):39-48.

\section{ANALYSIS OF BREAST PAIN CAUSING FACTORS DURING MAMMOGRAPHY \\ A. Martinkẻnas, B. Strukčinskienė, D. Šopagienė, D. Mažonaitè, S. Griškonis}

Keywords: mammography, pain during mammography, breast cancer.

Summary

Mammography is a particular radiological diagnostic test for imaging breast tissue, which helps diagnose malignant and benign changes in the breast. This test is used not only for diagnostic for patients with palpable lesions or other lesions but also in screening for breast cancer among asymptomatic women. Mammography examination has not only advantages but also disadvantages. One of the disadvantages is the pain, which prevents women from further mammography examinations. In mammography, pain is caused by breast compression, which is necessary to reduce the radiation dose, prevent motion artifacts, and obtain a flattened image of breast tissue.

The aim of the study - to reveal the factors that cause breast pain during a diagnostic mammography examination.

A anonymous survey was conducted in the $x$ Klaipeda hospital. The survey participants were 202 women in a preventive mammography program. The survey aimed to determine the factors causing pain during the mammography examination. Statistical analysis and data processing software Microsoft Office Excel 2016 and 
SPSS (version 27) were used to process the study data and calculate the results. The the chi-square $\left(\chi^{2}\right)$ test was used to assess the depedence of the variables. By comparing the statistical difference between the study groups, the reliability was checked according to Student's and Z's criteria. The results are considered statistically significant when $\mathrm{p}<0.05$. The study results showed that $57 \%$ did not feel pain, while $43 \%$ of respondents felt pain. $23 \%$ percent of women feel mild pain and $11 \%$ experience moderate pain during mammography. Severe pain was felt among $6 \%$ and very severe among $3 \%$ of women. Pain depends on breast size, non-onset / onset of menopause, and painful breasts $(p<0.001)$. According to the survey, of all the respondents, $3 \%$ will not have a mammogram next time. Most of these women who refuse will not take this exami- nation due to the severe and very severe pain they feel during the mammography procedure.

Conclusions: According to the questionnaire results, it can be stated that the main factors that cause breast pain during mammography are breast size, unbegun menopause, painful breasts. Some women who have experienced severe or very severe pain would refuse such a study.

Correspondence to: arvydas.martinkenas@ku.lt

Gauta 2021-09-28 